\title{
From Eco Marine Mart to Ecotourism: Development of Local Wisdom and Marine Creative Economy as Tourism Excellence
}

\author{
Alkhudri, A. $\mathrm{T}^{1}$, Heriyanto $\mathrm{N}^{2}$, Zulfikar $\mathrm{F}^{3}$, Sukiman ${ }^{4}$, Nugroho $\mathrm{T} \mathrm{T}^{5}$ \\ ${ }^{1}$ Faculty of Social and Political Science, University State of Jakarta \\ ${ }^{2}$ Rural Sociology,SKPM -FEMA, IPB, Bogor Agricultural University \\ ${ }^{3,4,5}$ Faculty of Social and Poltical Science, University State Jakarta. \\ a) Corresponding author:alkhudri@unj.ac.id
}

\begin{abstract}
This study aims to describe the potential of ecotourism in the development of local wisdom and the creative economy of marine as a leading tourism object. The research was conducted on the people of Harapan Island and Kelapa Island, in the Thousand Islands Regency, DKI Jakarta Province. The approach used in this research is a descriptive qualitative approach and Focus Group Discussion (FGD) using primary data sources obtained through observation and indepth interviews with creative economy entrepreneurs. This research involved community organizations, namely the Tourism Awareness Group (Pokdarwis) and the community as informants and 15 creative economy entrepreneurs. The research was conducted from 7 August to 28 September 2020. The results showed that the development of tourism on the islands of Harapan and Coconut prioritizes ecological sustainability. Meanwhile, the interaction between ecomarine and pokdarwis has been shown to increase visitors and increase the economic level of the community.
\end{abstract}

Keywords: Ecotourism, Creative Economy, Ecology.

\section{INTRODUCTION}

Tourism is one of the promising sectors to be developed in relation to earning foreign exchange, providing jobs, and encouraging development in an area, even tourism has become the largest industry in the world, including in Indonesia [1]. The tourism sector is currently expanding to a wide variety of sectors, not only tourism objects with dimensions of using sophisticated facilities and vehicles. Nature tourism, especially in the area of Harapan Island and Coconut Island, is an alternative for many tourist destinations. Moreover, natural tourism and conventional tourism on the island of coconut and island of hope still show the beauty and authenticity of nature, so that visitors can enjoy the natural beauty of coastal communities.
Therefore, good tourism management is when the tourism sector can provide benefits to all communities. This can be seen when small businesses in the community are involved in the tourism industry. Ecotourism-based tourism development according to is a combination of tourism development between nature conservation, involvement of local communities, cultural preservation and sustainable use of natural resources. tourism development by involving local communities aims to maintain the sustainability of the culture, customs and local wisdom of a place. Ecotourism-based tourism has the hope that profit sharing from tourism businesses will be more directly accepted by the community and by maintaining ecological principles. In addition, tourism development 
in involving the community can also affect the creative economy industry in the region.

In this case the creative industry develops so rapidly in tourism objects. That way, in addition to generating income from intellectual property, the creative economy also plays a very important role in creating sustainable economic value and green economy because creative economic resources will be renewable and will not run out and decrease. Creativity will inspire other creativity. Because the potential for thinking, imagining and human reasoning is always developing and dynamic. As long as science and technology develop, intellectual property as an economic resource will develop and scarcity will be overcome.

Therefore, the current prospective tourism potential of Harapan Island and Coconut Island, supported by good community support, existing local arts and culture, and the roles of supporting stakeholders in this case Pokdarwis and Eco Marine, will facilitate the achievement of this ecotourism development, According to three main pillars of ecotourism development will be realized: nature (flora and fauna) is sustainable (natural conservation); sustainable local arts and culture (local culture conservation); and improving local economic welfare (improving economic welfare for the locals).

Ecotourism-based tourism development in Harapan Island and Kelapa Island will be able to increase the role and active participation of the village community, village government, and other tourism stakeholders so that a new awareness will emerge about the importance of optimizing well-planned and sustainable tourism development. (sustainable). so that it will lead to the birth of an increase in the number of visitors and also an increase in the economy of coastal communities. This ecotourism-based tourism development will be able to improve the welfare of the community around the area and the image (imaging \& branding) of special tourism (ecotourism) on the coconut island and the island of hope.

\section{THE CONCEPT OF ECOTOURISM}

Ecotourism Concept The basic concept or fundamental principle of ecotourism is a combination of tourism development between nature conservation, involvement of local communities, cultural preservation and sustainable use of natural resources. Then The International Ecotourism Society, TIES (2000) defines ecotourism or ecoturism as a responsible nature tour by conserving the environment and improving the welfare of local communities. Ecotourism development must really be carried out with care and careful management, not trapped or tempted by short-term economic benefits, but must be guided by sustainable development.

Ecotourism can be understood as a deliberate trip to natural areas to understand the culture and history of the environment while keeping the area's integrity unchanged and generating opportunities for the income of the surrounding community so that they benefit from efforts to conserve natural resources. In this case, the involvement of local communities is very important to maintain local wisdom in the area. Ecotourism development must really be carried out with care and careful management, not trapped or tempted by shortterm economic benefits, but must be guided by sustainable development. This means that current and future generations can have the right to benefit from the same natural resources.

Furthermore, the concept of ecotourism offers an economic concept based on ecosystem principles. Where, development will not only generate economic growth, but also ensure ecological and social sustainability. In addition, the ecotourism concept also offers tourism activities that prioritize aspects of nature conservation and improving community welfare [2].

\section{MARINE CREATIVE ECONOMY}

Creative economy is a form of creative effort, innovation and exploration of people's ability to create and utilize existing natural resources and transform them into different forms and views. Like the opinion [3] which says that the creative economy is an industry that produces products of individual creativity, abilities and talents that have the potential to create jobs and pass them on to the next generation. In addition, the creative economy also leads to works that have selling value and have marketing.

The emergence and development of creative economic activities is now mushrooming, especially in Indonesia. Indonesia as a developing country and one of the countries with the largest population in the world has the potential to generate economic production. In addition, Indonesia is also a country that has a lot of potential natural resources, such as forest products, agriculture, plantations and even fisheries and marine. These natural resources can be processed into creative economy products and get a high selling value.

According to [4], the creative economy is closely related to the cultural industry. This means that the creative economy in each country is very dependent on the competence of human resources because society is the actor who produces the creative economy itself. The 
term creative economy according to Bocella also refers to the production and consumption of cultures that have certain characteristics and symbols, such as music, fashion design and especially distinctive forms of handicrafts. As an explanation of the main point in the paragraph above that the creative economy will develop along with the high quality of human resources. This can be strengthened by the idea of creative economy according to Simon Moreton. Moreton argues that educational activities can affect the development of the creative economy through research and product development through cooperation or partnerships with stakeholders, and undertaking product commercialization efforts. Then the point to emphasize in this section is the need for the role of institutions as agents that educate the public so that skills and competencies are increased to cultivate and build a creative economy. Marine creative economy has the potential to generate high GDP in a country. In addition, the marine creative economy covers several sectors such as the maritime economy, maritime catches and culture and the development of maritime or marine tourism.

Giang and Nguyen [5] argue that the creative economy in the maritime tourism sector can invite many people to come and make promises on regional income. This maritime tourism sector can hold various festivals to attract more people, make water sports, explore the island, culinary, history, or local cultural festivals. The export / import and export / import ship building sector and aquaculture and marine product processing can open many jobs and increase the income of many people but contribute greatly to the economic structure. Then according to things that are no less important to develop a marine economy are implementing ease of administration, increasing environmental-oriented business investment, increasing investment in the marine creative economy and mobilizing effective resources to develop business investment are things that need to be considered.

\section{METHODOLOGY}

This research was conducted using a qualitative approach. This research method uses a qualitative approach that looks at the production of the creative economy of kelutan in the people of Harapan Island and Kelapa Island, Kepulauan Seribu, DKI Jakarta Province. This research was conducted in the period MarchAugust 2020. Qualitative research has a style that attempts to construct reality. The author's case study method tries to develop an in-depth analysis of a case in the intended phenomenon. The case is then limited by activity and time, and in this research, it seeks to collect complete data and information based on the prescribed procedure.

The data collection techniques use the observation process, in-depth interviews with creative economy entrepreneurs and methods (focus group discussions) to explore problems and see real social conditions in depth. This study involved community organizations, namely the tourism awareness group (POKDARWIS) and the community who became informants and focus group discussions of 15 creative economy entrepreneurs. Then this research also performs documentation in order to visually immortalize data to prove social phenomena that occur in real terms. Data analysis uses qualitative data analysis which is better known as interactive model data analysis. In qualitative research, data analysis is the process of arranging data sequences, organizing them into a categorical pattern and basic unit description. According to Burhan Bungin in data categorization is adjusted to the formulation of the questions posed in this study and is intended to provide easy interpretation, selection, and explanation in the form of analysis descriptions.

\section{RESULTS AND DISCUSSION}

\subsection{Sociography and Landscape of Natural Resources in Kelapa Island and Pulau Harapan}

Harapan Island and Pulan Kelapa are two adjacent islands and these two islands are located in the same administrative area, located in North Seribu Islands District, Prov. DKI Jakarta. The presence of a bridge was built to connect the two islands, namely the Kelurahan Pulau Kelapa and Kelurahan Pulau Harapan. The Thousand Islands as we know them are located around the Java Sea and $68 \mathrm{~km}$ away from the provincial government center. DKI Jakarta. The total area of the two islands is around 503.19 (Ha) consisting of Kelapa Island 258.47 Ha, and Harapan Island Area (Ha) 244.72 Ha. Kelapa Island has 36 small islands and Harapan Island has 30 small islands. These two islands, including having a large population. In fact, the total population in Kelapa Island is 7627 and the population on Harapan Island is 2400, with the number of men being 3366 and the number of women being 3362 on Kelapa Island and the number of men being 1175 and the number of women being 1125 on Harapan Island. Has a total of 1869 Family Cards (KK) on Kelapa Island and 586 KK 
on Harapan Island with $5 \mathrm{RW}$ and $31 \mathrm{RT}$ on Kelapa Island and $3 \mathrm{RW}$ and $15 \mathrm{RT}$ on Harapan Island (BPS 2019).

The average population works as fishermen, traders, laborers and civil servants. The community has quite intense social interactions with others. It can be observed that the community can mingle with one another by forming social groups that aim to build social and economic activities such as Tourism Awareness
Groups, Joint Business Cooperatives, youth organizations and PKK. People in this area carry out MSME economic activities such as street vendors, grocery stores and food stalls to fulfill their daily needs. Several business actors also have tourism sector businesses in the form of lodging and fisheries cultivation. Fishermen business actors have types of boats and motorboats for the main transportation to catch fish, even these boats are often used for sea transportation services and crossing between islands.

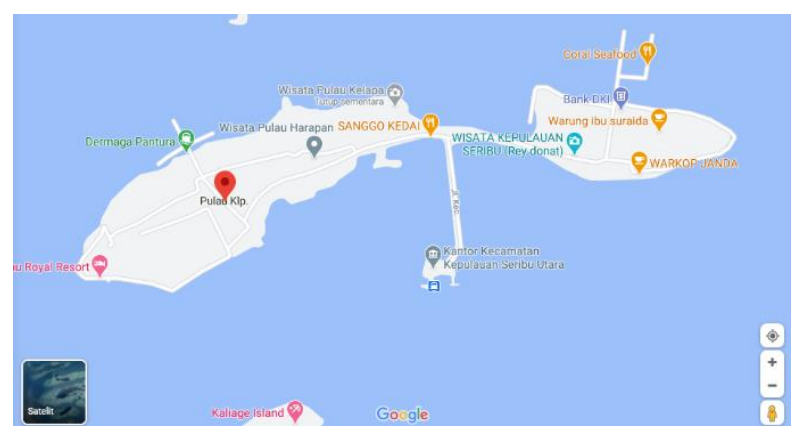

\section{Figure 1.Map of Harapan Island and Kelapa Island (BPS Data, 2019)}

The geographic location of these two islands, which are very close to the sea, makes it possible for the community to work as fishermen. The beautiful and exotic geographical conditions make it possible to attract wasatawan, therefore most of the people are engaged in the creative economy of marine and tourism. Apart from fishermen, the marine creative economy sector includes tourism development, souvenir production, island culinary delights as well as lodging and MSMEs.

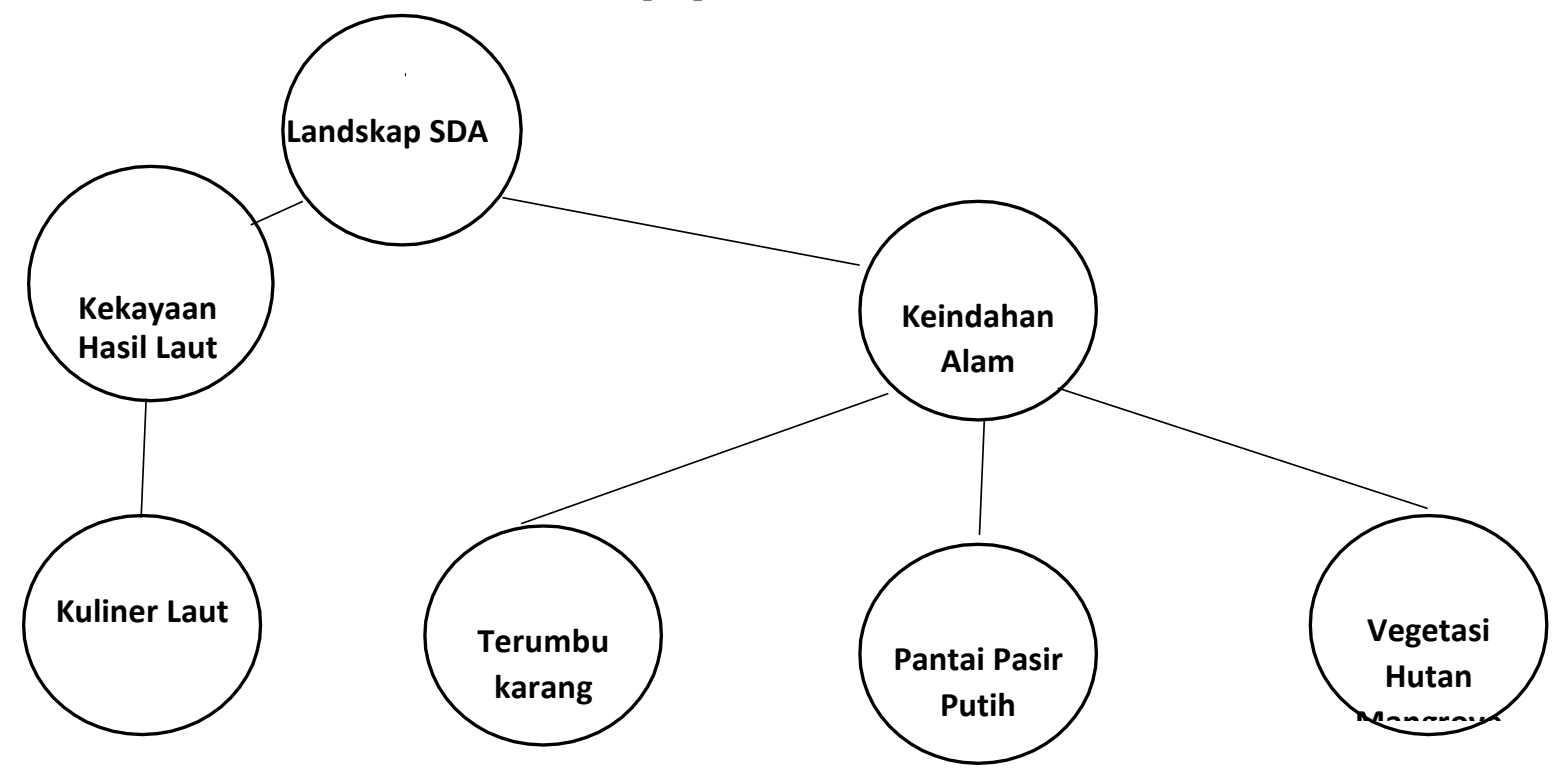

Figure 2. Landscape Schematic of Pulan Harapan SDA and Kelapa Island 
The schematic above attempts to describe the landscape of natural resources found in Harapan Island and coconut. Natural resources that can clearly be seen as tourism potentials and have high attractiveness are marine wealth and natural beauty. In the marine wealth sector, there are various catches of fishermen in the form of variations of fish, shrimp, squid and many more, which are the basic ingredients for processed seafood (seafood), of course, including special processed innovations such as crispy selar, squid stick. Artiiya is a wealth of seafood with interesting processing and presentation and delicious taste that can attract tourists.

Next, the natural beauty sector can also be a tourism potential that is no less attractive. The natural beauty that can be found by tourists is beautiful coral reefs that can be an attraction for tourists who want to enjoy the underwater beauty by diving (snorkeling). The white sand beach along with clear blue sea water is a very beautiful place for tourists to enjoy the beautiful sunset (sunset). This has become one of the tours favored by many people from various circles. Next is mangrove vegetation (mangrove) which is also interesting to be visited by tourists. This mangrove is a type of plant that grows on the edge of the beach, this plant is also commonly used to withstand sea waves coming to the land to reduce abrasion. In addition, this plant can become a habitat for sea creatures that live around it. Mangroves can also beautify the scenery around the coast and make the surrounding air fresher and more comfortable for the tourism sector.

The entire sector is very important to be developed and preserved in order to generate potential opportunities for environmental-based tourism. The preservation and care of all these sectors is also a way for tourism managers to provide education about how important it is to care for nature so that it can be enjoyed in a sustainable time. So that from this, humans can get multiple multiples, namely economic benefits, comfort, tourism satisfaction and sustainability.

\subsection{Population Dynamics and Cultural Properties}

The population of Harapan Island and Kelapa Island is dominated by Mandar and Bugis ethnic groups who are both married to the Betawi ethnic group. The Betawi ethnic group itself originates from the northern coastal areas of Tangerang, such as Mauk and Kronjo. Residents of the North Seribu Islands call this ethnic Betawi group the people of Banten. The indigenous people themselves have a little trouble identifying their ethnic identity. There are those who call themselves the Mandar, Bugis, Banten ethnic groups, and there are also those who call the three groups their identity.

After settling in the Thousand Islands, the Mandar people had a lot of business relations with the North Tangerang area. They sell fish to the Mauk and Kronjo areas. Apart from selling fish, they also buy the necessities of life in this area. In this trade relationship, many Mandar people meet their soul mate in the area. Many Mandar men married women from the Mauk and Kronjo areas. After getting married, they then settled and developed in the Thousand Islands. In the following period, many ethnic groups also came and settled on the Thousand Islands. These ethnic groups include Bugis, Madurese, Sundanese, Javanese, Malay, Minangkabau, and belong to the Mandar ethnic group who came after the first generation. The ethnic groups came gradually and continuously. The Bugis ethnic group is one of the largest ethnic groups in the region apart from the Mandar ethnic group.

The traditions that developed on the islands of Harapan and Kelapa do not form a unique cultural unity, but rather reflect the values of the culture of each ethnic group. Residents in this region themselves do not carry out many cultural practices that represent the identity of their ethnic group. Traditions or customs that are still carried out by the community are traditions related to the life cycle. These traditions include wedding ceremonies, births, and deaths in accordance with the customs and traditions of each ethnic group. The daily life of residents in this area is based on the condition of the area which consists of small islands and is surrounded by the sea, so it cannot be separated from the existence and functions of the sea. The routine activities of most parents are fishing. They do not go to sea every Friday. This is related to the religion of Islam which is followed by the majority of citizens. Friday is a day of worship (Friday prayers) so they stop their daily activities on Friday.

The mixing of people from various ethnic groups in the North Thousand Islands region makes the everyday language used by the local population unique. Community interactions that have been going on for a long time have resulted in a mixture of the language they use daily. The uniqueness of this language can be seen in the several syllables used, where there are syllables from several regional languages of existing ethnic groups. The accent language used is quite distinctive, which resembles the Sulawesi accent (Mandar and Bugis) but also mixed with the thick Betawi (North Tangerang) accent. The local people refer to the language they speak as 'pulo language'. 
There are no customary norms or rules that apply in the North Seribu Islands District. The norms or rules that apply in this area are the rules in accordance with the laws and regulations of the Republic of Indonesia. Even so, the kinship ties that occur between inhabited islands can be said to be quite close. This close kinship creates harmonious social relations that they carry out. High community trust in each other also creates a sense of security in the community. It is rare to find cases of theft or other crimes in the area.

\subsection{Eco Marine Mart and Marine Tourism Development}

Eco Marine Mart is here as a marine economy institutional model based on ecology using the principles of sustainability. The existence of Eco marine mart as an offline and online economic platform will be able to reach more consumers and can increase the number of creative economy product production. Besides that, increasing the number of tourism visits through promotion using the Eco Marine application can provide an economic increase to the surrounding community. In this case the products of the archipelago creative economy are in the form of:

\subsubsection{Product creativity}

This product is a form of utilization of natural resources that exist in coastal areas, usually in this case in the form of handicrafts, souvenirs in the form of decorations made from sea shells which are also created with other materials such as sand grains. Handycraft products produced by the people of Harapan Island and Kelapa Island, come from natural marine resources in the region. The types of handcraft that are produced are three-dimensional paintings, wall hangings, sculptures, and other accessories. These materials are taken without destroying the balance of nature.

They only use natural resources that are not used and are damaged. For example, like crafts made from coral reefs. These coral reefs are collected by communities from abandoned shorelines, and tend to endanger tourists when left unchecked. After being collected, the coral reefs are then sold to collectors or craftsmen to form a ready-to-sell product. For handicraft products made from coral reefs, they are formed into statues or wall decorations. As for sea sand, people use it for painting and for shells, which are usually used to make accessories for key chains.

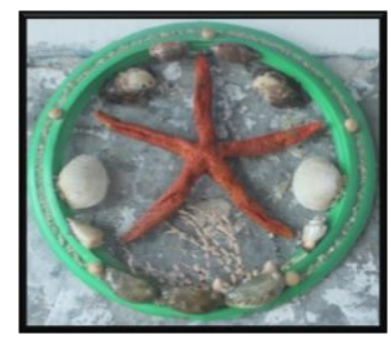

\section{Figuring Island Handicraft Drawing}

The price of each item tends to vary depending on the size and difficulty in the production process. For sand painting crafts, the price is IDR $100 \mathrm{~K}-200 \mathrm{~K}$. Meanwhile, coral reef wall hangings are priced at IDR $100 \mathrm{~K}-200 \mathrm{~K}$ and sculptures made of seashells priced around IDR $150 \mathrm{~K}-250 \mathrm{~K}$. Even so, in practice, the creative economy of the people of Harapan Islands and Kelapa Island, there are several obstacles, such as the difficulty of marketing distribution outside the island and difficult licensing of resource extraction. In addition, the availability of raw materials for production such as rope, glue and paint, which are still rarely sold in Harapan Island and Kelapa Island, makes handicraft production often hampered. This is because these raw materials can be purchased in Jakarta, and the price is higher because they have to pay costs from the island to the mainland. Apart from having to spend more capital, the weather is often a barrier to production.

\subsubsection{Eco-friendly products}


Environmentally friendly products are the utilization of natural resources through materials that are in sustainable packaging and free from harmful chemicals for the survival of the marine ecosystem. In this case, the use of natural resources is also well maintained by the community through harvesting marine products by ecological methods. The environmentally friendly products on Harapan Island and coconut use ingredients that are obtained directly from nature. The product of this product is in the form of marine products which are used as raw materials in the manufacture of various kinds of products, namely food products and handicraft products.

\subsubsection{Halal products}

The products of the creative economy in the coconut island region and hope in general do utilize the potential of natural resources around the island. The food, made from the natural resources available on the island. The food products are fish crackers, squid sticks, coconut roots and barongko. Food products produced by the people of Pulau Harapan and Pulau Kelapa also provide an economic boost through halal products.

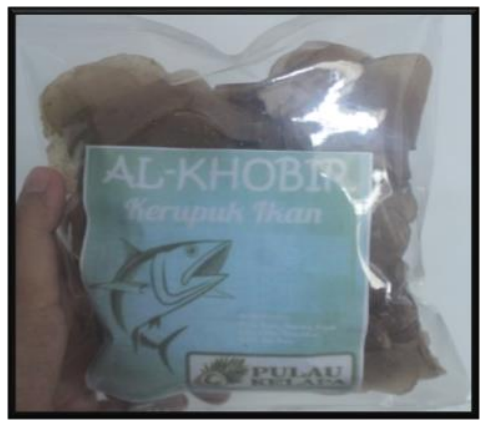

\section{Examples of Halal Islands Products}

\subsubsection{Halal destinations}

The tourist destinations on Harapan Island and coconut in tourism services on Harapan Island and Kelapa Island are in the form of a homestay business unit for visitors. The homestays are scattered in various places close to tourism spots, for example, white sand beach tours and turtle conservation. For now, the homestay is managed by the local community. Gelora Pulau Harapan and coconuts have started to grow since the beginning of 2012 following the popularity of the two islands that were well known before, Tidung Island and Pari Island. Often referred to by travelers who explore the islands of the Thousand Islands, if you have explored Harapan Island, you will feel the sensation of a natural adventure compared to other islands. Because of its strategic location, Harapan Island can reach other uninhabited islands which have been converted into tourist islands.

The condition of Harapan Island is still maintained, we can still get thousands of species of marine life such as coral reefs and fish which visitors can still enjoy while diving such as snorkeling and diving. Snorkeling, the activity I enjoy doing most when traveling on Pulau
Harapan. Has many unspoiled snorkeling spots with panoramic views of live corals scattered on several islands around Harapan Island. The quality of the snorkeling and diving spots is still well maintained. Because of this, diving is one of the very favorite activities. The sea water is clear, and the marine life that is preserved makes tourists come and is one of the most reliable tours, for snorkeling, diving or just releasing fatigue.

\subsection{The Future of Creative Economy and Tourism in the Archipelago}

Changes in the increasingly modern times today demand changes in sales patterns of services and products in a region. The sales pattern of services, in this case tourism services, must take advantage of technological and information developments in increasing product promotion. The use of technology can increase the target market and at the same time introduce the potential of Harapan Island and Coconut Island, both tourism service products and creative economy products. 
The strategy of using online media in marketing tourism service products and creative economy products is an obligation to compete and expand the potential for economic improvement and visitor visits. The potential of human and natural resources that exist in the people of Harapan Island and Coconut Island produces a picture that the community already has creative economic products. The developing tourism service also illustrates that the community can develop tourism based on ecotourism in the use of nature and sustainability.

Through Eco Marine, we can maximize the potential and provide a wider promotion of tourism services and products which can also increase the number of tourism visits and improve the community's economy. Moreover, Eco Marine can also help the ecological product packaging process and maximize attractive and sustainable packaging, such as the use of aluminum foil and recycled paper. That way, the marketing of products to be sold through the application can look more attractive and can reach market share both in coastal areas and in areas outside the coast.

In its development, various islands in the thousand islands will also be included in the Eco Marine application. In addition to products, stories about coastal areas will also be included in the application to provide knowledge about the islands. In the end, Eco Marine can become an information center and at the same time a center for the development of an ecologically based marine creative economy by promoting environmental sustainability principles.

\section{CONCLUSION}

This study aims to see the products and marketing of creative economy in Harapan Island and Kelapa Island, Thousand Islands and creative strategies that can be implemented in the future. The people of the Thousand Islands, especially those in Harapan Island and Kelapa Island, really support ecotourism in these areas by processing seafood by selling them directly through restaurants and eating places. The local community also produces handicrafts and provides lodging services, as well as traveling services to the tourists who attend.

Creative economic activities in Harapan Island and Kelapa Island utilize marine natural resources while maintaining ecological balance. Products sold are handicrafts, food and tourism services. For every material used to produce handicrafts, the community makes use of sea sand, clam shells, and dead coral reefs. Meanwhile, for food products, people process the fishermen's catch and make it a special food.

Therefore Eco Marine Mart is present as a marinebased creative economy that can provide an ecologically based marine economy institutional model using the principles of sustainability. The existence of an eco marine mart as an offline and online economic platform that can reach more consumers and can increase the production of creative economy products.

\section{REFERENCES}

[1] Mustaqim, M. (2018). Pengembangan Ekonomi Kreatif Desa (Studi Atas Pengembangan Ekowisata Cengklik, Blora). Jurnal Perspektif, 2(2), 267-283.

[2] Tegar, Dimas, Saut Gurning . (2018). Development of Marine and Coastal Tourism Based on Blue Economy. International Journal of Marine Engineering Innovation and Research. Vol. 2(2), pp.128-132.

[3] Kim, Taeyoung. "Creative Economy of the Developmental State: A Case Study of South Korea's Creative Economy Initiatives." The Journal of Arts Management, Law, and Society 47.5 (2017): 322-332.

[4] Fahmi, Fikri Zul, Philip McCann, and Sierdjan Koster. "Creative economy policy in developing countries: The case of Indonesia." Urban Studies 54.6 (2017): 1367-1384.

[5] Gianga, Tran Thi Quynh, and Nguyen Thi Thuy Ngab. "Potential development of marine economy in khanh hoa province." 